\title{
GMR
}

\section{In vivo antimutagenic effects of the Barbados cherry fruit (Malpighia glabra Linnaeus) in a chromosomal aberration assay}

\author{
E. Düsman ${ }^{1}$, I.V. Almeida ${ }^{2}$, L.T.D. Tonin ${ }^{3}$ and V.E.P. Vicentini ${ }^{2}$ \\ ${ }^{1}$ Departamento Acadêmico de Química e Biologia, \\ Universidade Tecnológica Federal do Paraná, Francisco Beltrão, PR, Brasil \\ ${ }^{2}$ Departamento de Biotecnologia, Genética e Biologia Celular, \\ Universidade Estadual de Maringá, Maringá, PR, Brasil \\ ${ }^{3}$ Universidade Tecnológica Federal do Paraná, Apucarana, PR, Brasil \\ Corresponding author: E. Düsman \\ E-mail: edusman@utfpr.edu.br
}

Genet. Mol. Res. 15 (4): gmr15049036

Received July 27, 2016

Accepted November 11, 2016

Published December 19, 2016

DOI http://dx.doi.org/10.4238/gmr15049036

Copyright (C) 2016 The Authors. This is an open-access article distributed under the terms of the Creative Commons Attribution ShareAlike (CC BY-SA) 4.0 License.

\begin{abstract}
Barbados cherry (BC) (Malpighia glabra Linnaeus) is a functional fruit that is consumed to prevent disease. It is used as an adjuvant in the treatment of several diseases, and acts as an antianemic, an appetite stimulant, a wound healer, an anti-inflammatory, a mineralizer, an antifungal, and an antioxidant agent. Several chemotherapeutic agents, such as cyclophosphamide, may result in undesirable side effects, and generate mutations in normal cells. Thus, the present study evaluated the antimutagenic potential of the fresh $(\mathrm{BCN})$ and frozen (BCF) juices of $\mathrm{BC}$ pulp, with and without concomitant administration of cyclophosphamide, using a chromosomal aberration test system in the bone marrow cells of Wistar rats treated in vivo for $24 \mathrm{~h}$. The results showed that neither the $\mathrm{BC}$ juice $(0.4 \mathrm{mg} / \mathrm{mL})$ alone, nor that
\end{abstract}

Genetics and Molecular Research 15 (4): gmr15049036 
with concomitant cyclophosphamide $(1.5 \mathrm{mg} / \mathrm{mL})$, were cytotoxic. $\mathrm{BC}$ has potential as an antimutagenic, and statistically reduced the percentages of chromosomal alterations induced by cyclophosphamide when administered simultaneously (BCN: 80.75\%; BCF: 88.26\%), pre-treatment (BCN: $86.85 \%$; BCF: $87.32 \%$ ), or post-treatment (BCN: $90.14 \%$; BCF: $86.85 \%$ ). This was due to the antioxidant activity of the fruit and the action of its bioactive compounds, which may have inhibited cyclophosphamide metabolism or scavenged the free radicals generated by this compound. Thus, attenuation of cyclophosphamide-induced mutagenicity suggests that the consumption of fresh or frozen $\mathrm{BC}$ should be encouraged for the prevention of disease, and for the maintenance and promotion of health.

Key words: Antioxidant; Nutraceuticals; Food technology; Chromosomal aberration; Bone marrow; Wistar rats

\section{INTRODUCTION}

Consumer interest in natural products and in health is growing, and is contributing to the increased consumption of fruits and their derivatives. The Barbados cherry fruit (BC) (Malpighia glabra Linnaeus) of the Malpighiaceae family, originally from the Antilles, is cultivated in the northeast of South America and Central America. It is considered to be a functional fruit that is consumed to prevent disease, or as a coadjuvant with some medical treatments (Nunes et al., 2011, 2013; Paz et al., 2015). The fruit has medicinal properties, and can act as an antianemic, an appetite stimulant, a wound healer, an anti-inflammatory, a mineralizer (Maia et al., 2007), an antifungal (Cáceres et al., 1993), and an antioxidant agent (Rufino et al., 2010; Oliveira et al., 2012). It has also been recommended for prevention of diseases, such as hypertension, cancer (Motohashi et al., 2004), viral hepatitis, varicella, polio, flu, colds, lung disorders, hepatic failure, and biliar vesicle irregularities (Assis et al., 2001).

$\mathrm{BC}$ is one of the most important natural sources of vitamin $\mathrm{C}$, and is better absorbed by the human body than synthetic ascorbic acid (Nunes et al., 2011; Delva and Goodrich-Schneider, 2013). In addition, the fruit contains vitamin A, carotene, vitamin B1, vitamin B2, anthocyanins, phenolic compounds, proteins, carbohydrates, and minerals, especially iron, calcium, and phosphorus (Mezadri et al., 2006; Adriano et al., 2011; Ribeiro da Silva et al., 2014).

The $\mathrm{BC}$ has great economic potential and is nutritious. It can be used to prepare different products, such as nectar, juice (integral, concentrated, lyophilized), liquor, ice cream, gelatin, gum, jam, jelly, and soda, and also to enrich juices and dietary products. This can be in the form of nutraceutical foods, such as tablets or capsules that are employed as food supplements, in addition to tea, sports drinks, nutritional bars, and yogurts (Freitas et al., 2006; Mezadri et al., 2006). However, it is most commonly marketed as fresh BC fruit, frozen pulp, and bottled juice (Yamashita et al., 2003; Adriano et al., 2011).

According to the Brazilian legislation of the Ministry of Agriculture (Brasil, 2000), the pulp is unfermented, not concentrated or diluted, and is obtained by crushing the fleshy fruit. This method of food processing increases the lifespan of these products, making them available for long periods of time, mainly outside of the harvest (Baptista and Venâncio, 2003). However, the quality, nutritional value, and nutraceutical benefits of these fruits must be preserved during the processing and storage periods (Agostini-Costa et al., 2003).

Genetics and Molecular Research 15 (4): gmr15049036 
Knowledge and perception on the benefits of natural foods have been used to identify new bioactive compounds through alternative pathways. In particular, many studies have investigated compounds that are present in foods and plants, and that have antimutagenic and/or an anticarcinogenic potential (Kaur et al., 2005; Berti et al., 2016). Antimutagenics are products or processes that reduce the frequency of spontaneous or induced mutations occurring (Erdtmann, 2003). The consumption of foods with these potential benefits provides a form of treatment that does not interfere with a patient's normal lifestyle, nor that requires the ingestion of an excessive amount of synthetic substances.

Several chemotherapeutic agents, such as cyclophosphamide (CP), may result in undesirable side effects and cause cellular mutations in organisms. We are of the opinion that the present study is the first to evaluate the potential protective effects and antimutagenic actions of the fresh and frozen pulp of $\mathrm{BC}$. We conducted an in vivo chromosome aberration test in the bone marrow cells of Wistar rats, in order to validate the consumption of this fruit with and without $\mathrm{CP}$. We investigated the co-adjuvant and antimutagenic effects of $\mathrm{BC}$ in the treatment of diseases and in the promotion of health.

\section{MATERIAL AND METHODS}

\section{Treatment solution}

Samples of fresh (BCN) BCs (M. glabra L.) were collected on the day of the experiment, from the Irenice Silva Medicinal Garden, at Universidade Estadual de Maringá (UEM), Paraná, Brazil ( $23^{\circ} 25^{\prime} \mathrm{S}, 51^{\circ} 57^{\prime} \mathrm{W}$ and at $542 \mathrm{~m}$ in altitude). The frozen pulp (BCF) of the BC (Brasfrut-Bahia-Brazil) was obtained from a commercial source and defrosted at the time of use. Juices were prepared in a blender, mixing $0.4 \mathrm{mg}$ pulp (fresh or frozen) in $1 \mathrm{~mL}$ water. This concentration exhibited no cytotoxic or mutagenic properties in a previous study conducted by our research group (Düsman et al., 2012).

\section{Bone marrow cells of Wistar rats}

Rats (Rattus norvegicus) of the Wistar lineage were obtained from the Central Biotery of UEM. Animals were 35 days old and weighed approximately $0.1 \mathrm{~kg}$ body weight (bw). Six animals, including three males and three females, were used for each negative and positive control and treatment groups, within one independent experiment.

The rat used in the antimutagenic analysis received $1 \mathrm{~mL}$ juice $(0.4 \mathrm{mg}$ pulp, BCN or $\mathrm{BCF}$, in $1 \mathrm{~mL}$ water $/ 0.1 \mathrm{~kg} \mathrm{bw}$ ) by oral gavage, before (pre-treatment $2 \mathrm{~h}$, PRE), with (simultaneous treatment, SIM), or after (2-h post-treatment, POST) the intraperitoneal administration of CP (Sigma, São Paulo, SP, Brazil) in $1.5 \mathrm{mg} / \mathrm{mL}$ water $/ 0.1 \mathrm{~kg}$ bw.

The negative control group (CO-) received $1 \mathrm{~mL}$ water $/ 0.1 \mathrm{~kg}$ bw by oral gavage. The positive control involved administration of $\mathrm{CP}$ at a concentration of $1.5 \mathrm{mg} / \mathrm{mL}$ in water $/ 0.1 \mathrm{~kg}$ bw, by intraperitoneal application. All of the animals were euthanized $24 \mathrm{~h}$ after the treatments.

\section{Ethical statement}

The animals were kept under controlled temperature $\left( \pm 25^{\circ} \mathrm{C}\right)$, humidity $( \pm 50 \%)$, and photoperiod (12 h light/dark) conditions. All of the ethical principles, protocols, and

Genetics and Molecular Research 15 (4): gmr15049036 
regulations on animal experimentation in the laboratory were applied and international standards were followed. All experiments were approved by the Ethics Committee on Animal Use in Experimentation/UEM, following the Ethical Principles in Animal Experimentation established by the Brazilian College of Animal Experimentation.

\section{Chromosome aberration (CA) test}

A CA test was performed using bone marrow cells from Wistar rats according to the method described by Ford and Hamerton (1956), with modifications.

The mitotic cell cycle was disrupted during metaphase by the intraperitoneal administration of colchicine $(0.5 \mathrm{~mL} / 0.1 \mathrm{~kg}$ bw) $(0.16 \%)$ (Acros Organics, Fair Lawn, NJ, USA). Colchicine was applied to each animal $1.5 \mathrm{~h}$ before euthanasia.

After collecting, fixing, and preparing bone marrow samples, the slides were stained and analyzed under a light microscope (Olympus KHC, São Paulo, SP, Brazil). One-hundred metaphase cells per animal were analyzed, for a total of 600 cells per control or treated group. The presence of CA was evaluated, and included gaps, breaks, and fragments. The data are reported as the percentage of the total number of alterations per metaphase, and the type of aberration is described along with the mutagenic or antimutagenic effect.

Cytotoxicity was evaluated by counting 5000 cells per sex totaling 10,000 cells per group, and then differentiating the phases (interphase, prophase, metaphase, anaphase, and telophase). Using these data, the percentage values for the mitotic index (MI) were calculated as the number of the dividing cells divided by the total number of cells present in the fields, multiplied by 100 .

\section{Statistical analyses}

The statistical calculations were performed using the Chi-square test $(\mathrm{N}=6, \alpha=0.05)$.

\section{RESULTS AND DISCUSSION}

Diets rich in fruits and vegetables have a positive impact on severe and chronic health conditions, such as obesity, diabetes, cancer, cardiovascular, and neurodegenerative diseases (Llacuna and Mach, 2012). The BC, among other fruits, is recommended as part of a diet to ensure a healthy life. It is important to evaluate the cellular effects of these fruits, especially in organisms that are related to humans, as well as their metabolism, digestion, and excretion; therefore, Wistar rats were used in this study.

The results of this study show that fresh $\mathrm{BC}$ juice, or its frozen pulp, administered alone, or together with $\mathrm{CP}$, exhibit $\mathrm{MI}$ values $(\mathrm{BCN}$ : $\mathrm{BC}=1.5, \mathrm{SIM}=1.2, \mathrm{PRE}=1.4, \mathrm{POST}=$ 0.9 and $\mathrm{BCF}: \mathrm{BC}=0.7, \mathrm{SIM}=1.1, \mathrm{PRE}=1.2, \mathrm{POST}=1.0)($ Table 1$)$ that are not significantly different to the negative control $(\mathrm{CO}-=1.4)$. Administration with $\mathrm{CP}(\mathrm{CP}=1.1)$ showed no cytotoxic activity. Additionally, the two pulps tested (fresh and frozen) had similar effects on the mitotic index in the antimutagenic treatment groups (SIM, PRE, and POST). Negative results for BC cytotoxicity were also found by Düsman et al. (2012), in an in vivo chromosomal aberration test using bone marrow cells of Wistar rats; by Almeida et al. (2013), in an in vitro micronucleus test using hepatoma cells of $R$. norvegicus; and by Horta et al. (2016), in an in vivo micronucleus test with the bone marrow cells of mice.

Genetics and Molecular Research 15 (4): gmr15049036 
Table 1. Mean percentages for the mitotic index (MI) and chromosomal alterations (CA).

\begin{tabular}{|c|c|c|c|c|}
\hline \multirow[t]{2}{*}{ Groups } & \multicolumn{2}{|c|}{ MI } & \multicolumn{2}{|c|}{$\mathrm{CA}$} \\
\hline & Fresh fruit & Frozen fruit & Fresh fruit & Frozen fruit \\
\hline $\mathrm{CO}-$ & \multirow{2}{*}{\multicolumn{2}{|c|}{\begin{tabular}{|l|}
1.4 \\
1.1
\end{tabular}}} & \multicolumn{2}{|c|}{0.3} \\
\hline $\mathrm{CO}+(\mathrm{CP})$ & & & & \\
\hline $\mathrm{BC}$ & 1.5 & 0.7 & 0.3 & 0.8 \\
\hline SIM & 1.2 & 1.1 & $4.1^{* \# S}(80.75 \%)$ & $2.5^{* \#}(88.26 \%)$ \\
\hline PRE & 1.4 & 1.2 & $2.8^{* H S}(86.85 \%)$ & $2.7^{* * \otimes}(87.32 \%)$ \\
\hline $\begin{array}{l}\text { POST } \\
\end{array}$ & 0.9 & 1.0 & $2.1^{* \# S}(90.14 \%)$ & $2.8^{* \# \notin}(86.85 \%)$ \\
\hline
\end{tabular}

Negative control: CO- (1 mL water); positive control: $\mathrm{CO}+(1.5 \mathrm{mg} / \mathrm{mL}$ cyclophosphamide - $\mathrm{CP})$; Barbados cherry fruit, fresh or frozen pulp: $\mathrm{BC}(0.4 \mathrm{mg} / \mathrm{mL})$; simultaneous treatment: SIM; pre-treatment: PRE; post-treatment: POST. Percentage in brackets represent the reduction in chromosomal alterations compared with the $\mathrm{CO}+(\mathrm{CP})$. *Statistically different from the negative control groups (CO-). "Statistically different from the $\mathrm{CO}+$ group (CP).

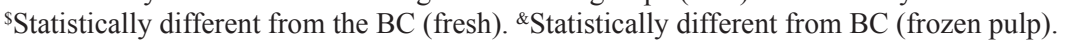

Motohashi et al. (2004) also found that extracts of Barbados cherry fruit were not cytotoxic to normal human periodontal ligament fibroblasts or gingival fibroblasts. However, these extracts were highly cytotoxic to oral squamous cell carcinomas and the human submandibular gland. Hanamura and Aoki (2008) found that a polyphenol extract from BC was not toxic to rats following $24 \mathrm{~h}$ of treatment $(2000 \mathrm{mg} / \mathrm{kg} \mathrm{bw})$, nor after 28 or 90 days of treatment $(100,300$, and $1000 \mathrm{mg} / \mathrm{kg} \mathrm{bw})$.

Thus, in the absence of any cytotoxic or mutagenic effects of BC (Düsman et al., 2012), and considering the proven anti-tumor effects of the fruit extracts, the protective effects of this fruit following exposure to $\mathrm{CP}$ were evaluated. This fruit has been used to treat a wide range of neoplastic diseases, as well as certain non-malignant lesions, such as rheumatoid arthritis, which are also responsible for producing secondary tumors (Anderson et al., 1995).

The data in Tables 1 and 2 and Figure 1 shows that the antimutagenic treatments with the $\mathrm{BC}(\mathrm{BCN}$ and $\mathrm{BCF})$ were statistically different from the treatment that was done only with the $\mathrm{CP}$ drug $\left(\chi^{2}-\mathrm{BCN}: \mathrm{SIM}=72.15, \mathrm{PRE}=122.23\right.$, POST $=175.54$ and $\mathrm{BCF}: \mathrm{SIM}=$ $141.37, \mathrm{PRE}=128.13, \mathrm{POST}=122.23)$. Thus, the $\mathrm{BC}$ was found to be a potential protective/ antimutagenic agent. $\mathrm{BCN}$ reduced the percentage of chromosomal alterations induced by CP by $80.75 \%$ (SIM), $86.85 \%$ (PRE), and $90.14 \%$ (POST). BCF reduced this percentage by $88.26 \%$ (SIM), $87.32 \%$ (PRE), and $86.85 \%$ (POST). Almeida et al. (2013) corroborated the results of the present study. They demonstrated that the juice of fresh $\mathrm{BC}$ reduced the mean number of iodine-131 radiation-induced micronuclei in hepatoma cells of $R$. norvegicus in vitro by $50 \%$. Other studies have also demonstrated the antimutagenic effects of the Barbados cherry fruit by the front matter of mutagen hydrogen peroxide (Nunes et al., 2011, 2013); with a comet assay using blood cells from mice and radiopharmaceutical iodine-131 (Düsman et al., 2014); with a chromosomal aberration test using the bone marrow cells of Wistar rats and iron; and with a micronucleus test using the bone marrow cells of mice (Horta et al., 2016). Additionally, Byrsonima verbascifolia, another plant of the Malpighiaceae family, reduced the damage induced by doxorubicin, another antineoplastic compound, by a SMART test using somatic cells from Drosophila melanogaster (Mendanha et al., 2010).

$\mathrm{BC}$ markedly reduced the mutagenicity of $\mathrm{CP}$ and this action was greater than $80 \%$. Despite this, the results obtained for the antimutagenic groups were different from those obtained for the negative control $\left(\chi^{2}-\mathrm{BCN}\right.$ : $\mathrm{SIM}=48.13, \mathrm{PRE}=20.83$, POST $=10.80$, and $\mathrm{BCF}: \mathrm{SIM}=16.13, \mathrm{PRE}=19.20, \mathrm{POST}=20.83$, Table 2$)$ and $\mathrm{BC}$ only $\left(\chi^{2}-\mathrm{BCN}: \mathrm{SIM}=\right.$ 48.13, $\mathrm{PRE}=20.83, \mathrm{POST}=10.80$, and BCF: $\mathrm{PRE}=4.51, \mathrm{POST}=5.00$, Table 2). 
Table 2. Final result from the total Chi-square test, based on average values for chromosomal abnormalities (CA).

\begin{tabular}{l|c|c|c|c|c|c|c|c|c}
\hline & \multirow{2}{*}{ CO+ } & \multicolumn{2}{|c|}{ BC } & \multicolumn{2}{|c|}{ SIM } & \multicolumn{3}{c|}{ PRE } & \multicolumn{2}{c}{ POST } \\
\cline { 3 - 11 } & & Fresh & Frozen & Fresh & Frozen & Fresh & Frozen & Fresh & Frozen \\
\hline CO- & $1470^{*}$ & 0.00 & 0.83 & $48.13^{*}$ & $16.13^{*}$ & $20.83^{*}$ & $19.20^{*}$ & $10.80^{*}$ & $20.83^{*}$ \\
\hline CO+ & - & 1470 & $525.31^{*}$ & $72.15^{*}$ & $141.37^{*}$ & $122.23^{*}$ & $128.13^{*}$ & $175.54^{*}$ & $122.23^{*}$ \\
\hline BC fresh fruit & - & - & 0.83 & $48.13^{*}$ & - & $20.83^{*}$ & - & $10.80^{*}$ & - \\
\hline BC frozen fruit & - & - & - & - & 3.61 & - & $4.51^{*}$ & - & $5.00^{*}$ \\
\hline SIM BC fresh fruit & - & - & - & - & 0.62 & 0.41 & - & 0.97 & - \\
\hline PRE BC fresh fruit & - & - & - & - & - & - & 0.00 & 0.23 & - \\
\hline POS BC fresh fruit & - & - & - & - & - & - & - & - & 0.23 \\
\hline SIM BC frozen fruit & - & - & - & - & - & - & 0.01 & - & 0.03 \\
\hline PRE BC frozen fruit & - & - & - & - & - & - & - & - & 0.00 \\
\hline
\end{tabular}

Negative control: CO- (1 mL water); positive control: $\mathrm{CO}+(1.5 \mathrm{mg} / \mathrm{mL}$ cyclophosphamide); Barbados cherry fruit, fresh or frozen pulp: $\mathrm{BC}(0.4 \mathrm{mg} / \mathrm{mL})$; simultaneous treatment: SIM; pre-treatment: PRE; post-treatment: POST. *Chi-square $\geq 3.84$ indicates a statistically significant difference between the parameters evaluated at the $5 \%$ significance level.

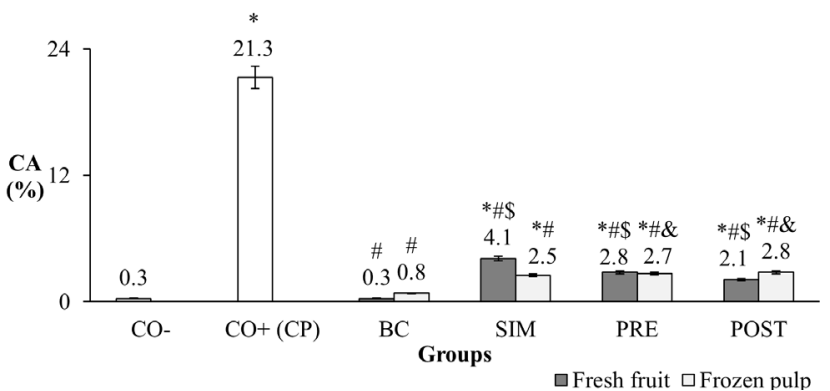

Figure 1. Mean percentages and standard deviations of chromosomal alterations (CA). Negative control: CO- (1 $\mathrm{mL}$ water); positive control: $\mathrm{CO}+(1.5 \mathrm{mg} / \mathrm{mL}$ cyclophosphamide); Barbados cherry fruit, fresh or frozen pulp: $\mathrm{BC}$ $(0.4 \mathrm{mg} / \mathrm{mL})$; simultaneous treatment: SIM; pre-treatment: PRE; post-treatment: POST. $(\mathrm{N}=6$, one independent experiment). *Results statistically different from the negative control groups CO-. "Results statistically different from the $\mathrm{CO}+$ (cyclophosphamide - CP). ${ }^{\$}$ Results statistically different from BC (fresh). ${ }^{\text {RResults statistically }}$ different from $\mathrm{BC}$ (frozen pulp).

Notably, only antimutagenic treatment administered simultaneous with the frozen pulp of $\mathrm{BC}$ led to chromosomal alterations that were statistically similar to the group that was treated only with this juice $\left(\chi^{2}-\mathrm{BCF}\right.$ : SIM $=3.61$, Table 2$)$.

The mechanism of Barbados cherry fruit's antimutagenic action is closely linked to the mutagenic actions of $\mathrm{CP}$ and the physicochemical composition of the fruit itself. For example, $\mathrm{CP}$ induced mutagenicity is related to the formation of cytotoxic metabolites and phosphoramide mustard, through the intermediary agents hydroxycyclophosphamide and descloroetilcyclophosphamide, which are able to induce cross-linking and breaks in the DNA (De Salvia et al., 1999). Thus, BC may have inhibited CP metabolism, and consequently, the formation of phosphoramide mustard, reducing the level of chromosomal damage in the bone marrow cells of treated rats.

$\mathrm{CP}$ may have also inactivated the microsomal enzymes, promoted lipid peroxidation, and increased the production of reactive oxygen species and other free radicals (Anderson et al., 1995). Thus, the antioxidant activity of BC may have been responsible for the antimutagenic activity of the fruit, sequestering the free radicals generated by $\mathrm{CP}$, resulting in the lower levels of chromosomal alterations observed in these groups. The antioxidant activity of BC is

Genetics and Molecular Research 15 (4): gmr15049036 
mainly attributed to its high vitamin C (VC) content $[\mathrm{BCN}=1960 \mathrm{mg} \mathrm{VC} / 0.1 \mathrm{~kg}$ pulp, Düsman et al. (2014), and $\mathrm{BCF}=1232 \mathrm{mg} \mathrm{VC} / 0.1 \mathrm{~kg}$ pulp]. The antimutagenic activity of $\mathrm{VC}$ has been confirmed in other studies, in particular, by Vijayalaxmi and Venu (1999), with concentrations of 10,30 and $60 \mathrm{mg} / \mathrm{kg}$ of this vitamin inhibiting the genotoxicity of CP $(50 \mathrm{mg} / \mathrm{kg})$, using test-system cells derived from the bone marrows of mice treated in vivo, in a manner similar to the present study. Nunes et al. (2011) corroborated this finding, stating that the protective effects exerted by $\mathrm{BC}$ may be related to $\mathrm{VC}$ and its complex mixture of nutrients. These compounds can interact with DNA and protect it from oxidative stress (Nunes et al., 2011), such as that induced by CP.

Research has highlighted that phytochemicals, such as the phenolic compounds, in addition to vitamins $\mathrm{C}$ and $\mathrm{E}$ and the carotenoids, contribute to the antioxidant activity of fruits and vegetables (Ratnam et al., 2006); therefore, they exhibit protective and antimutagenic properties. In this sense, the antimutagenic activity of $\mathrm{BC}$ juice, which was evaluated in the present study, may be due to $\mathrm{VC}$ as well as to a mixture of chemical compounds that are present in the fruit, such as phenolic compounds, anthocyanins, carotenoids, and flavonoids (Almeida et al., 2013; Düsman et al., 2014), together with vitamins A, B1, B2, and B3, as well as calcium, iron, sodium, and phosphorus.

Furthermore, a comparison of the chromosomal alterations induced by the two different pulps tested (fresh and frozen), also presented similar values during the simultaneous treatment $\left(\mathrm{BCN}=4.1\right.$ and $\left.\mathrm{BCF}=2.5, \chi^{2}=0.62\right)$, pre-treatment $(\mathrm{BCN}=2.8$ and $\mathrm{BCF}=$ $\left.2.7, \chi^{2}=0.003\right)$, and post-treatment $\left(\mathrm{BCN}=2.1\right.$ and $\left.\mathrm{BCF}=2.8, \chi^{2}=0.23\right)$ groups (Tables 1 and 2). Thus, frozen pulp of the $\mathrm{BC}$, which was processed and stored, showed the same antimutagenic potential as the fresh fruit. This is consistent with the findings of Chaves et al. (2004), who noted that the high content of ascorbic acid present in BC provides the potential for its industrialization and storage, without incurring any major nutritional disadvantages. Consequently, the beneficial effects of $\mathrm{BC}$, as an antimutagenic agent, have been demonstrated in the present study by the fresh and the frozen pulp.

In conclusion, these data support the commerce and consumption of the $\mathrm{BC}$, fresh or as frozen pulp, which is a product that is easy to handle and plant, at a relatively low cost. This provides a strong basis to support the consumption of this fruit in the prevention of disease and for the maintenance and promotion of health. $\mathrm{BC}$ reduced the mutagenic effects induced by the chemotherapeutic agent cyclophosphamide.

\section{Conflicts of interest}

The authors declare no conflict of interest.

\section{ACKNOWLEDGMENTS}

We thank the research group of the Laboratory of Mutagenesis and Environmental Monitoring, Universidade Federal de Maringá, PR, Brasil, and Coordenação de Aperfeiçoamento de Pessoal de Nível Superior (CAPES).

\section{REFERENCES}

Adriano E, Leonel S and Evangelista RM (2011). Fruit quality of Barbados cherry trees cv. Olivier in two stages of maturity. Rev. Bras. Frutic. 33: 541-545. http://dx.doi.org/10.1590/S0100-29452011000500073

Genetics and Molecular Research 15 (4): gmr15049036 
Agostini-Costa TS, Abreu LN and Rossetti AG (2003). Efeito do congelamento e do tempo de estocagem da polpa de acerola sobre o teor de carotenóides. Rev. Bras. Frutic. 25: 56-58. http://dx.doi.org/10.1590/S0100-29452003000100017

Almeida IV, Düsman E, Heck MC, Pamphile JA, et al. (2013). Cytotoxic and mutagenic effects of iodine-131 and radioprotection of acerola (Malpighia glabra L.) and beta-carotene in vitro. Genet. Mol. Res. 12: 6402-6413. http:// dx.doi.org/10.4238/2013.December.10.1

Anderson D, Bishop JB, Garner RC, Ostrosky-Wegman P, et al. (1995). Cyclophosphamide: review of its mutagenicity for an assessment of potential germ cell risks. Mutat. Res. 330: 115-181.http://dx.doi.org/10.1016/0027-5107(95)00039-L

Assis SA, Lima DC and Oliveira OMMF (2001). Activity of pectinmethylesterase, pectin content and vitamin C in acerola fruit at various stages of fruits development. Food Chem. 74: 133-137. http://dx.doi.org/10.1016/S0308$\underline{8146(01) 00104-2}$

Baptista P and Venâncio A (2003). Os perigos para a segurança alimentar no processamento de alimentos. 1st edn. Forvisão Consultoria em Formação integrada.

Berti AP, Palioto GF and Rocha CLMSC (2016). Antimutagenicity and antigenotoxicity of Aloe arborescens Miller and Aloe barbadensis Miller in Aspergillus nidulans and Wistar rats. Genet. Mol. Res. 15: gmr.15038522.

Brasil (2000). Ministério da Agricultura do Abastecimento. Instrução Normativa $n^{\circ}$ 01/00, de 07/01/00, Regulamento técnico geral para fixação dos padrões de identidade e qualidade para polpa de fruta. Diário Oficial da República Federativa do Brasil, Brasília, DF. Seção I: 54-58.

Cáceres A, López B, Juárez X, del Aguila J, et al. (1993). Plants used in Guatemala for the treatment of dermatophytic infections. 2. Evaluation of antifungal activity of seven American plants. J. Ethnopharmacol. 40: 207-213. http:// dx.doi.org/10.1016/0378-8741(93)90070-L

Chaves MCV, Gouveia JPG, Almeida FACA, Leite JCA, et al. (2004). Caracterização físico-química do suco da acerola. Rev. Biol. Ciên. Terra 4: 1-10.

De Salvia R, Fiore M, Aglitti T, Festa F, et al. (1999). Inhibitory action of melatonin on $\mathrm{H}_{2} \mathrm{O}_{2}$ - and cyclophosphamideinduced DNA damage. Mutagenesis 14: 107-112.http://dx.doi.org/10.1093/mutage/14.1.107

Delva L and Goodrich-Schneider R (2013). Acerola (Malpighia emarginata DC): Production, Postharvest Handling, Nutrition, and Biological Activity. Food Rev. Int. 29: 107-126. http://dx.doi.org/10.1080/87559129.2012.714433

Düsman E, Ferreira MFS, Berti AP, Mariucci RG, et al. (2012). Investigation of cytotoxic and mutagenic effects of Malpighia glabra L. (barbados cherry) fruit pulp and vitamin C on plant and animal test systems. Cienc. Tecnol. Aliment 32: 405-411. http://dx.doi.org/10.1590/S0101-20612012005000054

Düsman E, Berti AP, Mariucci RG, Lopes NB, et al. (2014). Radioprotective effect of the Barbados Cherry (Malpighia glabra L.) against radiopharmaceutical iodine-131 in Wistar rats in vivo. BMC Complement. Altern. Med. 14: 41. http://dx.doi.org/10.1186/1472-6882-14-41

Erdtmann BA (2003). Genotoxicidade Nossa de Todos os Dias. In: Genética Toxicológica (Silva J, Erdtman B, Henriques JAP Eds). Alcance: Porto Alegre.

Ford CE and Hamerton JL (1956). A colchicine, hypotonic citrate, squash sequence for mammalian chromosomes. Stain Technol. 31: 247-251.http://dx.doi.org/10.3109/10520295609113814

Freitas CAS, Maia GA, Costa JMC, Figueiredo RW, et al. (2006). Acerola: produção, composição, aspectos nutricionais e Produtos. Rev. Bras. Agrociênc 12: 395-400.

Hanamura T and Aoki H (2008). Toxicological evaluation of polyphenol extract from Acerola (Malpighia emarginata DC.) fruit. J. Food Sci. 73: T55-T61.http://dx.doi.org/10.1111/j.1750-3841.2008.00708.x

Horta RN, Kahl VFS, Sarmento MdaS, Nunes MFS, et al. (2016). Protective effects of acerola juice on genotoxicity induced by iron in vivo. Genet. Mol. Biol. 39: 122-128.http://dx.doi.org/10.1590/1678-4685-GMB-2015-0157

Kaur S, Michael H, Arora S, Härkönen PL, et al. (2005). The in vitro cytotoxic and apoptotic activity of Triphala--an Indian herbal drug. J. Ethnopharmacol. 97: 15-20. http://dx.doi.org/10.1016/j.jep.2004.09.050

Llacuna L and Mach N (2012). Papel de los antioxidantes en la prevención del cancer. Rev. Esp. Nutr. Hum. Diet 16: 1624. http://dx.doi.org/10.1016/S2173-1292(12)70067-4

Maia GA, Sousa PHM, Santos GM, Silva DS, et al. (2007). Efeito do processamento sobre componentes do suco de acerola. Ciênc. Tecnol. Aliment 27: 130-134. http://dx.doi.org/10.1590/S0101-20612007000100023

Mendanha DM, Ferreira HD, Felício LP, Silva EM, et al. (2010). Modulatory effect of Byrsonima verbascifolia (Malpighiaceae) against damage induced by doxorubicin in somatic cells of Drosophila melanogaster. Genet. Mol. Res. 9: 69-77.http://dx.doi.org/10.4238/vol9-1gmr678

Mezadri T, Fernández-Pachón MS, Villaño D, García-Parrilla MC, et al. (2006). [The acerola fruit: composition, productive characteristics and economic importance]. Arch. Latinoam. Nutr. 56: 101-109.

Motohashi N, Wakabayashi H, Kurihara T, Fukushima H, et al. (2004). Biological activity of barbados cherry (acerola fruits, fruit of Malpighia emarginata DC) extracts and fractions. Phytother. Res. 18: 212-223. http://dx.doi. org $/ 10.1002 /$ ptr. 1426

Genetics and Molecular Research 15 (4): gmr15049036 
Nunes RdaS, Kahl VFS, Sarmento MdaS, Richter MF, et al. (2011). Antigenotoxicity and antioxidant activity of Acerola fruit (Malpighia glabra L.) at two stages of ripeness. Plant Foods Hum. Nutr. 66: 129-135. http://dx.doi.org/10.1007/ s11130-011-0223-7

Nunes RdaS, Kahl VFS, Sarmento MdaS, Richter MF, et al. (2013). Genotoxic and antigenotoxic activity of acerola (Malpighia glabra L.) extract in relation to the geographic origin. Phytother. Res. 27: 1495-1501.

Oliveira LdeS, Moura CFH, De Brito ES, Mamede RVS, et al. (2012). Antioxidant metabolism during fruit development of different acerola (Malpighia emarginata D.C) clones. J. Agric. Food Chem. 60: 7957-7964. http://dx.doi. org/10.1021/jf3005614

Paz M, Gúllon P, Barroso MF, Carvalho AP, et al. (2015). Brazilian fruit pulps as functional foods and additives: evaluation of bioactive compounds. Food Chem. 172: 462-468. http://dx.doi.org/10.1016/j.foodchem.2014.09.102

Ratnam DV, Ankola DD, Bhardwaj V, Sahana DK, et al. (2006). Role of antioxidants in prophylaxis and therapy: A pharmaceutical perspective. J. Control. Release 113: 189-207.http://dx.doi.org/10.1016/j.jconrel.2006.04.015

Ribeiro da Silva LM, Teixeira de Figueiredo EA, Silva Ricardo NM, Pinto Vieira IG, et al. (2014). Quantification of bioactive compounds in pulps and by-products of tropical fruits from Brazil. Food Chem. 143: 398-404.http://dx.doi. org/10.1016/j.foodchem.2013.08.001

Rufino MSM, Alves RE, Brito ES, Pérez-Jiménez J, et al. (2010). Bioactive compounds and antioxidant capacities of 18 nontraditional tropical fruits from Brazil. Food Chem. 121: 996-1002. http://dx.doi.org/10.1016/j.foodchem.2010.01.037

Vijayalaxmi KK and Venu R (1999). In vivo anticlastogenic effects of L-ascorbic acid in mice. Mutat. Res. 438: 47-51. http://dx.doi.org/10.1016/S1383-5718(98)00161-2

Yamashita F, Benassi MT, Tonzar AC, Moriya S, et al. (2003). Produtos de acerola: estudo da estabilidade de vitamina C. Ciênc. Tecnol. Aliment 23: 92-94. http://dx.doi.org/10.1590/S0101-20612003000100019

Genetics and Molecular Research 15 (4): gmr15049036 